\title{
A NATUREZA JURÍDICA DO PROCESSO: RELAÇÃO JURÍDICA, SITUAÇÃO JURÍDICA E A NAVEGAÇÃO NA EPISTEMOLOGIA DA INCERTEZA
}

\author{
Valmor Júnior Cella Piazza
}

Resumo: Partindo das concepções modernas acerca da natureza jurídica do processo, o objetivo deste trabalho é apresentar uma visão diferente da majoritariamente estudada na academia. Com este fim, apresenta, as duas teorias mais aceitas pela comunidade jurídica ocidental: Brevemente, a Teoria da Relação Jurídica Processual de Oskar Von BÜLOW, com aporte bibliográfico de Adolf WACH e da clássica escola processual italiana, e sua contraposição através da Teoria da Situação Jurídica Processual de James GOLDSCHMIDT. Realiza um debate de ideias entre a Teoria de Exigência de Proteção Jurídica e sua contraposição na Teoria dos Imperativos. Investiga as categorias processuais apresentadas por ambos (direitos e obrigações de um lado, e expectativas, perspectivas, chances, riscos, cargas e liberação de cargas do outro) e conclui pela necessidade de incluir novas categorias e matérias, além da jurídica, à ciência processual para chegar à redenção de Piero CALAMANDREI com sua Teoria do Processo como um Jogo.

Palavras-chave: Natureza jurídica do processo. Relação jurídica. Situação jurídica. Proteção Jurídica. Processo como jogo. Categorias processuais.

1 Aluno do Módulo I da Escola Superior da Magistratura do Estado de Santa Catarina (ESMESC). Bacharel em Direito pela Universidade do Vale do Itajaí. E-mail: valmorcp@hotmail.com 


\section{INTRODUÇÃO}

O propósito deste artigo é descrever parte do caminho percorrido pelo grande processualista alemão, James GOLDSCHMIDT, em sua odisseia no confronto com as teorias dominantes acerca da Natureza Jurídica do Processo e da Proteção Jurídica. Desta forma, far-se-á uma breve apresentação da teoria da Relação Jurídica Processual de Oskar Von BULOW e seus principais expoentes.

Neste início, é importante frisar que o objetivo não é apresentar qual a real ou verdadeira natureza jurídica do processo, mas sim, através de construção teórica, determinar os motivos que embasam a necessidade de aceitação de novas doutrinas ao campo jurídico. O fundamento essencial de não optar, no decorrer deste trabalho, por tomar uma teoria como única verdade ao questionamento elaborado, é basicamente a cautela de não incidir no erro de acreditar na existência da verdade una no campo das ciências jurídicas.

Este trabalho será desenvolvido e apresentado seguindo o método dialético. Isto devido a necessidade de compreender que a produção científica deve ser guiada através da construção e diálogo de ideias, e não pela imposição de verdades. Por este motivo, apresentam-se durante todo o trabalho as disputas travadas por James GOLDSCHMIDT para expor seus pensamentos e as contra-posições apontadas pelos demais processualistas.

Primeiro com o próprio "almo" da ciência processual moderna, Oskar Von BULOW. Devido à escassa extensão do presente trabalho acadêmico, opta-se por suprimir muitos dos autores que ampararam e deram vida à Teoria da Relação Jurídica Processual. Da mesma forma, não se faz possível a apresentação de todos os conceitos e variações da presente doutrina. Entretanto, realiza-se, mesmo que en passant, uma exposição dos baluartes fundantes e da apreciação da escola processual italiana de Giusepe CHIOVENDA, Piero CALAMANDREI e 
Francesco CARNELUTTI frente à nova doutrina inserida no mundo jurídico.

Demonstram-se os conceitos teóricos evolvidos por Adolf WACH, um dos grandes aperfeiçoadores da referida teoria, e o enfrentamento feito por James GOLDSCHMIDT. Dá-se especial estudo ao debate sobre a finalidade do processo. Enquanto WACH defende o processo apenas como uma forma regrada para aplicação do direito material, GOLDSCHMIDT o contesta, afirmando que o processo tem como finalidade a obtenção de uma sentença favorável com força de coisa julgada.

A compreensão dos argumentos de James GOLDSCHMIDT torna-se fundamental neste ponto, para a apresentação do ápice desta nova teoria: A inserção de novas categorias processuais e a demonstração da grande insegurança jurídica que gera um processo. Comparações entre um processo e uma contenda militar demonstram quão sensíveis ficam os bens jurídicos durante a lide e, desta forma, a necessidade de inserir novas disciplinas no campo processual.

O arremate final está no testemunho de vários autores sobre a comparação do processo com um navio em mar aberto, e sua navegação na epistemologia da incerteza. Autores como Aury LOPES JR fazem referência a grandes nomes da ciência moderna, como Albert EINSTEIN, na tentativa de revelar como nem mesmo a matemática é cem por cento perfeita, quem dirá, então, o processo.

Para tanto, neste primeiro passo, opta-se por uma breve exposição da teoria fundamental do processo moderno, realizada por Oskar Von BÜLOW em 1868. Pois, o que havia até então era um enorme imbróglio entre direito material e direito processual. De certo ponto, pode-se até pensar que não era uma confusão, uma vez que o processo e o direito material eram a mesma coisa. Porém, aquele consistia em meros atos irregulares, que tinham por finalidade a busca da verdade real e a certeza 
da entrega do direito ao credor. Salvo raros autores ${ }^{2}$, que preconizaram uma leve e embrionária apartação entre estes ramos da ciência jurídica, até meados do século XIX não existia diferença entre Direito Processual e Direito Material.

O grande marco desta separação foi, sem dúvida alguma, os escritos em 1868 de OSKAR VON BÜLOW em sua principal obra "Die Lehre von den Processeinreden und die Processvoraussetzungen" 3 . Nesta obra, BÜLOW elaborou um resgate jurídico histórico do período romanista e, após séculos de confusão sobre a natureza jurídica do processo, afastou de vez o direito processual dos caminhos do direito material.

De tal grandeza foi esta obra, que ainda hoje, quase um século e meio depois, as raízes de suas teorias regam grande parte da doutrina ocidental e a esmagadora maioria dos autores nacionais (PIAZZA, 2009, p. 157 et seq). Ao conceber o "processo como uma relação de direito público, que se desenvolve de modo progressivo, entre o tribunal e as partes", BÜLOW (2005, p. 3-7) trouxe conceitos ocultos àquela época e desprezou "uma teoria equivocada e falseadora de todo o sistema processual civil" vigente.

\section{GERMÂNICOS E ITALIANOS - A CONVERGÊNCIA E CONCOMITANTE MULTIPLICIDADE DA RELAÇÃO PROCESSUAL}

As declarações de Oskar Von BÜLOW acerca das características do processo foram aceitas por grande parte dos mais respeitáveis processualistas, tanto de sua época, quanto da atualidade. ${ }^{4}$ Evidente que, cada qual, conforme a evolução

2 Os poucos autores localizados foram BÚLGARO, HEGEL e BETHMANNHOLLWEG.

3 Teoria das Exceções e dos Pressupostos Processuais - Tradução de Ricardo Rodrigues Gama. (BÜLOW, 2005)

4 Da Alemanha a teoria passou à Itália, com MORTARA, Commentario del Codice e delle Leggi di Procedura Civile, Milão, s. d., 2. ${ }^{\circ}$ vol., págs. 535 e segs; CHIOVENDA, primeiro na "preleção volonhesa" de 3 de fevereiro de 1903, reproduzida nos Saggi di Direitto Processuale Civile, Bolonha, 1904 (Ensaios de Direito Processual Civil), depois nos Principii di Direitto Processuale Civile, Nápoles, 1907, 
temporal, ou mesmo dentro de suas esferas egocêntricas, adaptaram, restringiram ou até mesmo ampliaram esta classificação, como v. g. Giuseppe CHIOVENDA (1998, p. 79), que classifica "a relação processual [em] uma relação autônoma e complexa, pertencente ao direito público".

Já Hélio TORNAGHI (1956, p. 31) entende que o processo pode ser visto de duas posições distintas. A primeira é a exterior, onde o processo é considerado como um procedimento. A segunda é quanto a sua essência, onde o processo deve ser visto como relação jurídica. Uma relação que se caracteriza "pela unidade, pela complexidade e pelo dinamismo. É a resultante, não apenas a soma, de tôdas [sic] as relações que no processo existem entre cada uma das partes e o juiz. É como um rio para o qual confluem todos os cursos d'água, sem deixar por isso de ser um rio só”.

Um dos seguidores mais destacados de BÜLOW, mas que não deixou de tecer severas críticas a teoria da relação processual e dos pressupostos processuais, foi Adolf WACH. Se foi BÜLOW quem criou a teoria da relação jurídica, foi WACH quem primeiro desenvolveu sistematicamente a ideia com sucesso. Em sua principal obra, intitulada Handbuch des deuts-

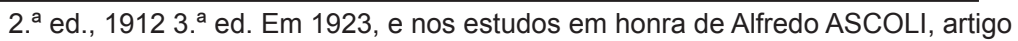
reproduzido nas págs. 163 e segs. Do $3 .^{\circ}$ vol. Dos Ensaios, e ROCCO (Alfredo), La sentenza civile, Turim, 1906. FERRARA (Luigi), La nozione dei rapporti processuali, nos Saggi di Direitto Processuale Civile, Nápoles 1914; ROCCO (U.), L'autorità, Roma, 1917, págs. 61 e segs. E págs. 294 e segs. Com especial referência ao processo penal: EISLER, Dire Prozess voraussetzungen im oesterreichischen Strafprozess, em Gruenhut Z., 17, 587; BINDING, Grundriss, págs. 185 e segs.; RULF-GLEISPACH, Der oesterreichische Strafprozess, págs. 2 e segs.; GLEISPACH, Das deutschoesterreichische Strafverfaheren, págs. 2 e 3; BELING, Der. Proc. Penal, págs. 71 e segs. MARTUCCI, Sulla teoria del rapporto giuridico processuale penale, na Rivista italiana di Diritto Penale, 1942, págs. 241 e segs.; Giuseppe GUARNERI, Sulla Teoria Generale del Processo Penale, págs. 1 a 87; ANGIONI, La natura del rapporto giuridico processuale nelle sue applicazioni al processo penale; MANZINI, Trattato, $1 .^{\circ}$ vol., págs. 72 e segs.; BORTOLOTTO, Saggio, págs. 3 e segs.; LANZA, Sistema, $1 .^{\circ}$ vol., páginas 483 e segs.; DE MAURO, Principii, pág. 19; CALAMANDREI, Instituciones, pág. 267. (TORNAGHI, 1956. 1v. 1t. p. 31). Piero CALAMANDREI apesar de ter sido adepto da Teoria da Relação Jurídica Processual, como ainda será visto neste artigo, no final de sua vida acabou mudando sua opinião para a Teoria da Situação Jurídica de James GOLDSCHIMDT, entendendo o processo como um "jogo". 
chen Civilprozessrechts ${ }^{5}$ de 1885 , o autor (1977, p. 64) destaca que "donde hay proceso, hay relacion jurídica [processual], relacionamento jurídico entre las personas participantes". E continua: "el proceso civil es una relación jurídica unitária, que se va desenvol-

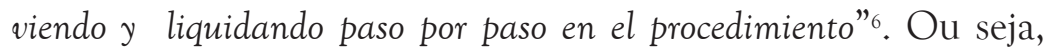
somente destas duas citações, pode-se determinar o conceito unitário e autônomo da relação jurídica processual para o autor.

Desta forma, percebe-se que a teoria da Relação Jurídica não é uníssona em suas classificações. Por exemplo, para o italiano Francesco CARNELUTTI (2004, p. 76) a relação jurídica processual é a composição de um conflito de interesses, mediante um mandato jurídico. Ou seja, é o direito atuando na composição de um conflito: "um conflito de interesses regulado pelo Direito. O conflito de interesses é seu elemento material; e o mandato jurídico, seu elemento formal".

Por haver uma discordância quanto ao direito material litigado, existe um conflito de interesses. Por haver um conflito de interesses, existem, no mínimo, dois pontos de vista distintos tentando prevalecer. A composição jurídica e a relação jurídica, são estabelecidas justamente com a finalidade e garantia que um destes interesses prevalecerá ao outro, e este outro se subordinará ao primeiro. Por este motivo, a relação jurídica é o encontro de dois interesses: um prevalecente ou protegido e outro subordinado (CARNELUTTI, 2004, p. 76).

Evidente que neste meio tempo outros autores também criticaram as teorias de BÜLOW. Alguns com críticas pontuais como Adolf WACH (1977), Josef KOHLER ${ }^{7}$ e Konrad HELLWIC $^{8}$ que elaboraram amplo debate, principalmente,

5 Manual de Direito Processual Civil Alemão. (WACH, 1977)

6 Aonde há processo, há relação jurídica, relacionamento jurídico entre as pessoas participantes. [...] O processo civil é uma relação jurídica unitária, que se desenvolve e liquida passo a passo no procedimento. (Tradução Livre)

7 KOHLER, Josef. Der Prozess als Rechtsverhaeltniss. Mannheim, 1888. p. 5 apud TORNAGHI, Hélio. Comentários ao Código de Processo Penal. Rio de Janeiro: Revista Forense, 1956. 1v. 1t. p. 28

8 HELLWIG, Konrad. Lehrbuch des Deutschen Civil-prozessrechts. Lipsia, 1903 1v. p. 4 apud TORNAGHI, 1956. p. 27 
sobre quais sujeitos participavam da relação jurídica processual (PIAZZA, 2009).

Autores como Giuseppe CHIOVENDA (1998), Francesco CARNELUTTI (2000), Piero CALAMANDREI (2003) (antes de fazer coro a James GOLDSCHMIDT), entre outros tantos, também efetivaram algumas críticas com relação à complexidade ou multiplicidade da relação jurídica. Porém, importante frisar que todas estas críticas/complementações foram elaboradas sem perder o foco central da teoria dominante da Relação Jurídica Processual.

\section{A RECONSTRUÇÃO DAS TEORIAS DE OSKAR VON BÜLOW E ADOLF WACH POR JAMES GOLDSCHMIDT}

Que Oskar Von BÜLOW foi figura distinta entre os processualistas modernos, é impossível negar. Que a Teoria da Relação Jurídica processual, por ele elaborada em 1868 na obra "Die Lehre von den Processeinreden und die Processvoraussetzungen", configura como literatura obrigatória dentre as grandes publicações acerca das categorias processuais, também é consenso. Que foi a partir de sua notável contribuição na elaboração dos pressupostos processuais que o "processo" ganhou forma, autonomia e foco dentre as ciências jurídicas, é fato evidente ${ }^{10}$. Porém, 57

9 Teoria das Exceções e dos Pressupostos Processuais - Tradução de Ricardo Rodrigues Gama. (BÜLOW, 2005)

10 A importância da obra de Oskar Von BÜLOW para a ciência processual é reconhecida por praticamente todos os doutrinadores desta ciência. Este reconhecimento passa deste os primeiros grandes seguidores de sua teoria, a contar por Adolf WACH, nas obras Conferencias Sobre La Ordeanza Procesal Civil Alemana e Manual de Derecho Procesal Civil, e seus compatriotas alemães Josef KOHLER (Der Prozess als Rechtsverhaeltniss) e Konrad HELLWIC (Lehrbuch des Deutschen Civil-prozessrechts), até os seguidores da chamada Escola Chiovendiana, como Giuseppe CHIOVENDA (Instituições de Direito Processual Civil), Francesco CARNELUTTI (Sistemas de Direito Processual Civil), Piero CALAMANDREI (Instituições de Direito Processual Civil) e, entre outros, Enrico Tullio LIEBMAN (Problemi del Processo Civile). Na doutrina nacional não é diferente, apesar do desleixo de alguns autores para com este tema, mesmo os que são contrários à tese da Relação Jurídica Processual admitem a importância e relevância da obra de BÜLOW para o primor atual alcançado pela ciência processual. A saber José Frederico MARQUES (Elementos de Direito Processual Penal e Manual de Direito Processual Civil), Hélio TORNAGHI (A Relação Processual Penal e Comentários ao Código de Processo Penal), 
anos após o triunfo de sua teoria, e navegação em uma maré tranquila de ideologias, surgiu a obra "Prozess als Rechtslage" ${ }^{11}$ e mais tarde Teoria General del Proceso de James GOLDSCHMIDT.

James GOLDSCHMIDT foi o principal opositor e crítico de Oskar Von BÜLOW na sua teoria da relação jurídica processual. Mais que isto, para além das críticas, o autor elaborou uma ampla e contundente doutrina acerca da natureza jurídica do processo. Esta doutrina viria a ser chamada Teoria da Situação Jurídica.

Para se fazer compreender, GOLDSCHMIDT (1961, p. 27) optou por iniciar seus trabalhos pela finalidade do processo. Contudo, necessitava, outra vez, quebrar os dogmas da principal teoria vigente, a teoria da exigência de proteção jurídica. Esta teoria, foi elaborada por Adolf WACH em seu trabalho Handbuch des Deutschen Zivilprozessrechts ${ }^{12}$, e ao ser confrontada por GOLDSCHMIDT deu lugar ao conceito de derecho justicial material e a tese de que a finalidade do processo é a pura e simples obtenção da coisa julgada.

Adolf WACH (1958, p. 22) entende que o processo é a forma legalmente regrada para aplicação do direito privado pelo Estado. Os órgãos que cumprem esta função são os tribunais. Desta forma, a tutela jurídica que estes tribunais concedem, nada mais é que a aplicação do direito privado, e, logo, o processo civil é a forma em que os tribunais transformam o direito objetivo privado em realidade. A finalidade de tornar real este direito, tem relação com a própria subordinação deste e visa tutelar os interesses jurídicos privados.

Aury LOPES JR. (Direito Processual Penal e sua Conformidade Constitucional), Eugênio PACELLI DE OLIVEIRA (Curso de Processo Penal), Paulo RANGEL (Direito Processual Penal), Fernando da Costa TOURINHO FILHO, que chega a adjetivar BÜLOW de gênio, (Processo Penal e Manual de Processo Penal), Rogério Lauria TUCCI (Teoria do Direito Processual Penal: Jurisdição, Acão e Processo), José Rubens COSTA (Manual de Processo Penal), entre outros (PIAZZA, 2009).

11 Processo como Situação Jurídica - Tradução do próprio James GOLDSCHMIDT. 12 WACH, Adolf. Manual de Derecho Procesal Civil. Buenos Aires: Ediciones Jurídicas Europa-America, 1977. 
El ordenamiento procesal es un ordenamiento de la tutela jurídica y, como tal, una figura secundaria, un medio para lograr el fin que es probar la eficacia del derecho privado. Para que el derecho no solamente exista, sino rija, debe existir el proceso. Mediante el proceso, el Estado hace valer el derecho frente a la conducta que está en pugna con éste y lo hace mediante la coerción, para someter esa conducta a la persecución judicial, mediante la declaración judicial autoritativa que se expresa en la sentencia (WACH, 1977, p. 22) ${ }^{13}$.

Portanto, para WACH, o processo é o ordenamento de uma tutela jurídica, "su misión no es crear derecho objetivo, sino satisfacer las exigencias del derecho" ${ }^{14}$ (1977, p. 24). Ou seja, a exigência de proteção jurídica para o autor é de índole totalmente processual.

Entretanto, GOLDSCHMIDT critica esta posição e afirma que ao invés de possuir uma índole processual e pública, a exigência de proteção jurídica está regrada no âmbito do derecho justicial material. Para o autor, "este no es otra cosa sino el Derecho privado considerado y completado dede un punto de vista juridico-público. Detrás de cada precepto del Derecho privado se encuentra su proyección en el Derecho justicial material"15 (1961, p. 29).

Detrás de quase todos os direitos subjetivos privados, encontram-se suas respectivas ações. Porém, em alguns casos, pode ocorrer de haver direito sem ação ou mesmo ações sem direito. Nestes casos, os preceitos legais que hão de regular manifestar-se-ão através da existência do Derecho justicial material de um modo imediato e simples.

$13 \mathrm{O}$ ordenamento processual é um ordenamento da tutela jurídica e, como tal, uma figura secundária, um meio para lograr o fim, que é provar a eficácia do direito privado. Para que o direito não somente exista, mas sim funcione, deve existir o processo. Mediante o processo, o Estado faz valer o direito frente a conduta que está em conflito com este, e o faz mediante a coerção, para submeter esta conduta a uma persecução judicial, mediante a declaração judicial oficial que se expressa na sentença. (Tradução Livre)

14 Sua missão não é criar direito objetivo, mas sim satisfazer as exigências de direito. (Tradução Livre)

15 Este não é outra coisa senão o direito privado considerado e completado desde um ponto de vista jurídico público. Detrás de cada preceito do direito privado se encontra sua projeção no direito justicial material. (Tradução Livre) 
No direito romano, o direito privado e o Derecho justicial material se coincidiam, uma vez que fora da ação não havia direito. GOLDSCHMIDT afirma que esta distinção iniciou por WINDSCHEID (1985 apud GOLDSCHMIDT, 1961, p. 32), mas se encerrou com o reconhecimento do caráter público da ação e sua equivalência com a exigência de proteção jurídica (GOLDSCHMIDT, 1961, p. 29-32) O autor explica:

Sin embargo, aun se encuentran, por un lado construcciones de la acción que desconoce su carácter público y, por otro, objeciones contra el concepto de la exigencia de protección jurídica, que establecen la imposibilidad procesal de una exigencia de sentencia de determinado contenido y del deber estatal de otorgala. Claro está que la base pública del proceso es sólo la exigencia abstracta del ciudadano de que el Estado administre justicia. (GOLDSCHMIDT, 1961, p. 35)

Com isso, fica claro que a crítica de GOLDSCHMIDT (1961, p. 33-34) a WACH consiste no caráter processual atribuído à exigência de proteção jurídica. Esta não é um direito menos material que aquele que a mesma protege. Para o crítico, quem desejar excluir a hipótese de haver direitos fora de uma sentença de fundo, teria evidentemente, que negar a própria existência de direitos materiais objetivos e em consequência, confundiria a existência com a evidência de direitos. Nesse sentido, conclui GOLDSCHMIDT:

Pero, evidentemente, el enfoque que prescinde de lo que llegará a ser un derecho en el proceso, no es procesal. La concepción procesal requiere, generalmente $[. .$.$] otras categorías. Por eso tampoco$ es procesal la base de la doctrina según la cual la exigencia de protección jurídica o de la acción es un derecho potestativo (constitutivo) que se ejer-

16 No entanto, mesmo que sejam, primeiras construções da ação que desconhece seu caráter público, e por outro lado, objeções contra o conceito da exigência de proteção jurídica, que estabelecem a impossibilidade processual de uma exigência de determinado conteúdo e o dever estatal de a outorgar. Fica claro, que a base pública do processo é apenas a exigência abstrata dos cidadãos de que o Estado administre a justiça. (Tradução Livre) 
cita en el proceso, porque cada sentencia absolutoria la refutaria.

\section{[...]}

La teoría según la cual la acción no vincula sino por medio de la sentencia, parte de un enfoque romanístico $y$, por consiguiente, civilístico de la acción, dándole una dirección contra el demandado y atribuyéndole como contenido, después del condemnari oportere, un iudicatum facere oportere (GOLDSCHMIDT, 1961, p. 33-34) $)^{17}$

A desconstrução de exigência de proteção do direito processual, e sua aceitação em um Derecho justicial material, retoma a necessidade da inserção de novas categorias jurídicas a explicar os complexos fenômenos processuais. Não se deve colocar o processo em dependência com o direito material para conseguir efetivar uma conexão com o seu objeto (que inexiste na relação jurídica processual). Muito pelo contrário, somente através da total independência do direito processual é que se poderá constatar a pressão e a ação exercida no direito material. Direito material este, que é o objeto do processo.

Para GOLDSCHMIDT, na busca da finalidade processual, deve-se compreender o conceito de processo. Porém, não aquele conceito metafísico que Adolf WACH sugeriu ${ }^{18}$, mas sim um conceito empírico visando sua realidade. Explica GOLDSCHMIDT:

17 Mas, evidentemente, o enfoque prescinde do que chegará a ser um direito no processo, não é processual. A concepção processual requer geralmente [...] outras categorias. Por isto também não é processual a base da doutrina segundo a qual a exigência de proteção jurídica ou de ação é um direito potestativo (constitutivo) que se exercita no processo, porque cada sentença absolutória a refuta. [...]

A teoria segundo, segundo a qual, a ação não vincula, senão por meio da sentença, parte de um enfoque romanístico e, por consequinte, civilístico da ação, dando uma direção contra o demandado e o atribuindo como conteúdo, depois do condemnari oportere, um iudicatum facere oportere. (Tradução Livre)

18 Acerca da característica metafisica do processo, Adolf WACH reserva uma nota de rodapé para buscar uma explicação desta conceituação. A nota é muito importante e de tem fundamental validade para a compreensão das características de uma sentença. Na versão em espanhol, que é a utilizada para este trabalho acadêmico, a referida nota ocupa 2 páginas praticamente completas e está localizada nas páginas 26,27 e 28 . Na versão original do livro, a nota está na página 7. Em ambas as edições a numeração da nota é 7 . 
El proceso es el procedimiento cuyo fin es la constitución de la cosa juzgada, es decir, del efecto de que la pretensión del actor valga en el porvenir ante los tribunales como jurídicamente fundada o no fundada. [...]. La cosa juzgada tiene el efecto de que lo que fue concedido por sentencia firme no puede impugnarse ya, y de que lo que fue denegado por sentencia firme no se puede hacer valer de nuevo. (GOLDSCHMIDT, 1961, p. 37) 19 $^{19}$

Em vista disso, deve-se compreender que a finalidade do processo não é a exigência de uma proteção jurídica do Estado, mas sim a busca pela constituição da coisa julgada. $\mathrm{Na}$ concepção de WACH, o direito processual acaba por ficar atrelado ao direito material e sua própria garantia de segurança jurídica. Já na concepção de James GOLDSCHMIDT a busca é pela exigência de uma garantia formal, com força de lei ${ }^{20}$ sobre o objeto do processo, que é o direito material.

Para WACH, a análise é feita com vistas em um fim ideal, já para GOLDSCHMIDT a análise é realizada segundo o sentido real do processo. GOLDSCHMIDT (1961, p. 39) explica que "al buscar el fin del proceso, hay que partir de su concepto empírico, investigar el fin, que en cada proceso se alcanza" ${ }^{21}$. E este fim não pode ser outro, senão o encerramento do conflito. Este encerramento também não pode ocorrer de outra forma, senão pela força vinculatória da coisa julgada.

19 O processo é o procedimento cujo fim é a constituição da coisa julgada, é dizer, o efeito que a pretensão do autor busca perante os tribunais como juridicamente fundada ou não fundada [...]. A coisa julgada em o efeito de que aquilo que foi concedido por sentença firme, não si pode impugnar mais, e o que foi negado por sentença firme não se pode fazer valer outra vez. (Tradução Livre)

20 Deve-se ter muito cuidado ao compreender a expressão "força de lei" neste caso. Não se deseja ampliar este vocábulo a determinada teoria existente de que a sentença tem caráter de lex specialis. Os seguidores desta teoria pretendem conceber uma base científica com fundamento no livre arbítrio do juiz e que este, ao proferir a sentença estaria preenchendo lacunas existentes na legislação de direito material. Muito pelo contrário, o termo "força de lei" se refere a uma vinculação que a coisa julgada cria e que seria semelhante à característica imperativa que a lei exerce sobre os cidadãos de um Estado.

21 Ao buscar o fim do processo, tem que partir de seu conceito empírico, investigar o fim que em cada processo se alcança. (Tradução Livre) 
Superadas as objeções quanto a finalidade do processo, James GOLDSCHMIDT (1961, p. 49) continua a desenvolver sua tese com a apresentação da natureza das normas jurídicas. Para o autor, estas possuem uma dupla natureza. Se por um lado representam imperativos aos cidadãos, por outro, e aqui atinge um ponto fundamental da teoria, são medidas para o juízo do juiz. Sua primeira função é exercida extrajudicialmente, e, por isto, considerada estática ou material. Já a segunda, a concepção dinâmica, se desenvolve durante o processo e necessita de categorias processuais, novas e adequadas, para ser compreendida.

A teoria dos imperativos foi criticada por vários autores, porém, GOLDSCHMIDT as rebateu e ratificou seu credo:

Quien pretenda refutar la teoria de los imperativos invocando la estructura de muchas normas, confunde contenido y forma. Tampoco tiene fundamento el reproche de que la teoría de los imperativos se deja llevar por el mandamiento del legislador (ita ius esto) que promulga la ley; la vigencia de ésta no es parte integrande de la norma. Finalmente se ha negado que [...] pueda explicar la esencia del Derecho subjetivo, puesto que éste, segun ella, no es sino el "reflejo" de un imperativo. Es verdad que hay deberes juridicos sin que frente a ellos existan derechos subjetivos correspondientes. Pero no exite Derecho subjetivo al cual no corresponda un deber, porque derechos subjetivos únicamente pueden imaginarse a base de un imperativo. (GOLDSCHMIDT, 1961, p. 50 et seq. $)^{22}$

Para o autor (1961, p. 51), analisando através da teoria dos imperativos, direito subjetivo não é aquilo que se proíbe

22 Quem pretende refutar a teoria dos imperativos invocando a estrutura de muitas normas, confunde conteúdo e forma. Também não tem fundamento a crítica de que a teoria dos imperativos se deixa levar pelo mandamento do legislador (ita ius esto) que promulga a lei; a vigência desta não está na parte integrante da norma. Finalmente se tem negado que [...] se pode explicar a essência do Direito subjetivo, posto que este, segundo ela, não é senão o "reflexo" de um imperativo. É verdade que existe deveres jurídicos, sem que frente a eles existam direitos subjetivos correspondentes. Mas não existe Direito subjetivo al qual não corresponda um dever, porque somente podem imaginar direitos subjetivos a base de um imperativo. (Tradução Livre) 
ou o que se permite, mas sim o poder de tornar eficazes aqueles imperativos jurídicos. Este poder do direito subjetivo deve ser atribuído ao próprio interessado, uma vez que o critério que o distingue das demais normas éticas não é a sua coercibilidade, sua heteronomia ou mesmo sua referência a uma conduta externa e extrajudicial, senão seu caráter atributivo de constituir direitos.

GOLDSCHMIDT (1961, p. 51) explica que "el fin del derecho es constituir derechos subjetivos, su meio es establecer deberes, es decir, emitir imperativos" 23 . Ou seja, na real natureza das normas como imperativos se baseiam os conceitos jurídicos "dever e direito". O "dever" é a sujeição a um imperativo, enquanto que o "direito" é o poder sobre um imperativo.

Como citado anteriormente, as normas jurídicas não são apenas imperativos dirigidos aos cidadãos, mas são também medidas para o juiz julgar suas condutas. GOLDSCHMIDT (1961, p. 54) pontua que "es evidetne que también los que han de someterse a la ley pueden juzgar según ella sus acciones y relaciones". Porém, nestes casos não estarão fazendo mais que adiantar a função estatal do juiz.

Uma ressalva é fundamental neste momento. Não há dúvidas que o juiz também tem nas normas, imperativos a serem seguidos. Entretanto, no momento em que as normas servem, não mais como imperativos, mas sim como medidas de um juízo, o juiz se veste da função Estatal de administrar justiça. Neste ponto está uma das grandes inovações da teoria: se o direito, para James GOLDSCHMIDT (1961, p. 54), serve como instrumento de medida para um juízo do juiz, este não seria súdito do direito, como defende Adolf WACH ${ }^{24}$, mas sim soberano a este.

23 é evidente que também os que se submeterão a lei podem julgar segundo ela suas ações e relações. (Tradução Livre)

24 "[...] se yerra si se piensa que el juez crea derecho por ser nueva la norma individual que se ha de aplicar, y que se obtiene por labor de combinación. Cuando el juez aplica la norma concreta al hecho-tipo, también toma esa norma del derecho objetivo, que no consiste en principios aislados e inconexos sino en la combinación y unidad de esos principios. Por lo tanto, la actividad del juez consiste en una a menudo muy complicada labor de intérprete, combinada con la subsunción con- 
GOLDSCHMIDT (1961, p. 54) faz uma metáfora com o pedreiro que constrói um muro: a norma jurídica é "instrumento mediante el cual el juez juzga del mismo modo que el albañil se sirve de la plomada para enderezar el muro" 25 . Ou seja, o juiz acaba, de certa forma, por moldar ou até mesmo criar direito. $\mathrm{O}$ autor complementa:

De ahí que, según la opinión que concibe el derecho como medida para el arbtirio judicial, el juez mismo no puede ser sujeto u objeto de ligamenes jurídicos. Conforme a ese criterio el juez se halla por encima y, por lo tanto, fuera del derecho; la jurisdicción es, como hemos visto anteriormente, "metajurídica". Semejante afirmación no ha de entender erróneamente. Evidentemente no quiere significarse con ello el absurdo principio: iudex legibus solutus. El juez se vincula por el derecho, porque es juez, es decir porque la aplicación del derecho es su ofício.

$[\ldots]$

creta, la conclusión dedutiva y la declaración arbitral, pero no es nunca legislativa. [Nota ao texto]

La lei es la voluntad que lo domina, y no una voluntad que es dominada por él. La voluntad que coadyuva a concretar el ordenamiento jurídico está contrapuesta a la voluntad legislativa y el poder dispositivo que se le ha asignado debe entenderse como un poder cualitativamente distinto, que solamente ejecuta. En nuestros tiempos [meados e final do século XIX e início do século XX] se ha ocupado detalladamente de esta normación jurídica concreta Bülow, [...] concordando substancialmente, según creo, con lo dicho y con lo que ha sido hasta ahora la opinión general. Non deben llevarnos a engaño ciertas espresiones que parecian discrepar de esta opinión y suponer que el juez o el particular tuvieran una especie de poder legislativo derivado. Asi por ejemplo, cuando Bülow habla, como muchos otros, de la sentencia como lex specialis, cuando relaciona con el juez el proverbio: "la autoridad es un derecho vivo, la ley una autoridad muda", o cuando entiende la volición del particular o del juez, que ayuda a generar la relación jurídica concreta, como un órgano auxiliar autorizado del derecho objetivo. El derecho objetivo no es complementado o desarrollado en una "norma jurídica concreta", ni se expresa tampoco en la voluntad del juez o del particular una potencia nomotética que le es ínsita y reconocida por la legislación, sino que el derecoh existente se aplica al caso por él previsto, sea produciendo un supuesto de hecho, sea subsumiendo ese supuesto, mediante un juicio, bajo la ley. [...]" (WACH, 1977. p. 25-26)

25 Instrumento mediante ao qual o juiz julga, do mesmo modo que o pedreiro se serve do cimento para construir/corrigir o muro. (Tradução Livre) 
Para la consideración de que tratamos, el decir que el juez no puede se sujeto $u$ objeto de ligámenes juridicos, estriba en que, según ella, representa el poder soberano, cuya existencia y actividad es, ni más ni menos, condición para que se produzcan nexos juridicos. (GOLDSCHMIDT, 1961, p. 55-56) ${ }^{26}$

A partir das considerações do direito como instrumento de juízo do juiz, e da função que o juiz desempenha no processo, deduz-se os nexos jurídicos e os laços processuais ${ }^{27}$ das partes. A natureza das normas jurídicas como medida do juízo do juiz, resulta para as partes, promessas ou ameaças de determinada conduta deste juiz. Conduta esta, de conteúdo determinado e com efeito juridicamente fundado na pretensão de cada indivíduo no processo.

\section{AINSERÇÃODENOVAS CATEGORIASPROCESSUAIS E A DINAMICIDADE DA TEORIA}

Neste sentido, GOLDSCHMIDT (1961, p. 57) declara que "los nexos jurídicos de los individuos que se constituyen correlativamente, son expectativas de uma sentencia favorable o perspectivas de una sentencia desfavorable" 28 . Porém, antes da sentença existe um processo, e para o autor, o processo é como uma luta pelo direito. Por isso as citadas expectativas de uma sentença favo-

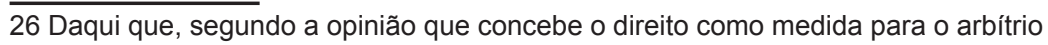
judicial, o juiz não pode ser sujeito ou objeto de ligamentos jurídicos. Conforme este critério, o juiz está acima e portanto, fora do direito; a jurisdição é, como vimos anteriormente, "metajurídica". Semelhante afirmação não deve ser entendida erroneamente. Evidentemente não se quer significar com isto, o absurdo princípio: iudex legibus solutus. O juiz se vincula pelo direito, porque é juiz, e porque a aplicação do direito é seu ofício. (Tradução Livre)

27 Importante frisar que estes laços processuais das partes são de cada parte para com o processo e não entre as partes. Quando falamos de laços das partes com o processo, indicamos as categorias implementadas por James GOLDSCHMIDT a natureza jurídica do processo. Caso falássemos de laço entre as partes, estaríamos caindo em grave equívoco, pois estaríamos retomando a existência de uma relação entre as partes no processo. Relação esta abominada pela teoria da Situação Jurídica de GOLDSCHMIDT.

28 Os nexos jurídicos dos indivíduos que se constituem correlativamente, são expectativas de uma sentença favorável ou perspectivas de uma sentença desfavorável. (Tradução Livre) 
rável dependem, normalmente, do sucesso de um ato processual da parte interessada. Por outro lado, as perspectivas de uma sentença desfavorável dependem sempre da omissão de um ato processual da parte (des)interessada.

O posicionamento com relação ao sucesso ou omissão de um ato processual, para aumentar as referidas expectativas ou perspectivas, se dão ao extremo em um processo de partes. Em um processo inquisitivo, onde o juiz é dotado de iniciativa probatória, estas categorias acabam por não depender apenas dos indivíduos. Porém, quanto mais democrático e assemelhado a um perfeito processo de partes for, onde a iniciativa probatória e a produção de material processual depende somente destas partes, mais haverá a necessidade de disposição para obter sucesso em seus atos processuais.

Com relação aos atos e o sucesso ou omissão destes, o autor leciona:
Ahora bien, la parte que se encuentra en situación de proporcionarse mediante un acto una ventaja procesal, y en definitiva, una sentencia favorable, tiene una posibilidad u ocasión procesal29. [...] Por el contrario, cuando la parte tiene que ejecutar un acto para prevenir un perjuicio procesal, y en definitiva una sentencia desfavorable, le incumbe una carga procesal $^{30}$. (GOLDSCHMIDT, 1961, p. 58, grifo do autor $)^{31}$

29 O autor cita vários exemplos de possibilidades e ocasiões processuais. A começar pela possibilidade de fundamentar a demanda, de propor ou produzir provas, especialmente de apresentar documentos, de replicar, de contestar a demanda, ou até mesmo a possibilidade propor exceções dilatórias ou peremptórias, etc. (GOLDSCHMIDT, 1961, p. 58)

30 Como exemplos de cargas processuais, o autor cita a necessidade de comparecer ao processo para que não seja declarado em revelia, a carga do demandado de contestar a demanda ou de produzir provas contrárias à do autor. (GOLDSCHMIDT, 1961, p. 58)

31 A parte que se encontra em situação de proporcionar mediante um ato, una vantagem processual, e em definitivo uma sentença favorável, tem uma possibilidade ou ocasião processual. [...] Ao contrário, quando a parte tem que executar um ato para prevenir um prejuízo processual, e em definitivo uma sentença desfavorável, incumbe-a uma carga processual. (Tradução Livre) 
Excepcionalmente a lei pode dispensar a parte de liberar uma carga. Tais casos ocorrem v. g. quando o juiz se declara incompetente de ofício. Porém, regra geral este tipo de dispensa se da pelas presunções legais, onde a própria lei estabelece a dispensa da produção de provas pela parte favorecida. Vide exemplo o direito do réu no processo penal de permanecer calado.

GOLDSCHMIDT (1961, p. 59) afirma que existem direitos, somente, em sentido processual. Estes direitos são formados por três categorias: As expectativas de uma sentença favorável, a dispensa de uma carga processual, e a possibilidade de sucesso ao realizar um ato processual. $\mathrm{O}$ autor adverte que "en realidad, no se trata de derechos propiamente dichos, sino situaciones que podrian denominarse con la palabra francesa: chances $^{32}$ " (grifo do autor)..$^{33}$

Portanto, frente a uma chance, a parte tem possibilidade de se livrar de uma carga processual e ir em direção a uma sentença favorável, ou não aproveitar a chance e seguir rumo a uma sentença desfavorável. (LOPES JR, 2008, p. 42)

Estas três classes de direitos processuais podem ser comparadas às três classes fundamentais de direitos materiais: As expectativas de uma vantagem processual, igualam-se aos direitos relativos, uma vez que há a necessidade de um juiz as satisfazer. As dispensas de cargas processuais são comparadas aos direitos absolutos, devido a estes estarem a salvo de qualquer prejuízo. $\mathrm{E}$ as possibilidades de sucesso ao realizar um ato processual, estariam equiparadas com os direitos potestativos ou constitutivos. Por outro lado, a carga processual, que tem a finalidade

32 Aury LOPES JR. traz algumas definições para esta palavra francesa: "1. Maneira favorável ou desfavorável segundo a qual um acontecimento se produz (álea, acaso); potência que preside o sucesso ou insucesso, dentro de uma circunstância (fortuna, sorte. 2. Possibilidade de se produzir por acaso (eventualidade, probabilidade). 3. Acaso feliz, sorte favorável (felicidade, fortua. Na definição do dicionário Le Petit Robert, Paris: Dictionnaires Le Robert, 2000, p. 383 (tradução nossa)." (LOPES JR., 2008a, p. 42)

$33 \mathrm{Na}$ verdade, não se trata de direitos propriamente ditos, mas sim situações que poderiam ser denominadas com a palavra francesa: chances. (Tradução Livre) 
de prevenir um prejuizo ou uma sentença desfavorável, poderia ser comparada com o conceito material de obrigação ou dever. (GOLDSCHMIDT, 1961, p. 59-60)

Importante compreender que todos os direitos processuais estão em uma relação causal com um ato processual. A finalidade deste ato processual é evidenciar um fato ou a produção de uma prova. O autor (GOLDSCHMIDT, 1961, p. 72) explica que "todos los derechos procesales se encuentran en una relación de espera con una resolucion judicial, regularmente con la sentencia" ${ }^{34}$. As situações jurídicas da concepção processual, não são meios para um fim, mas sim objetos substantivos para o julgamento. Desta forma, entende-se que os direitos processuais não são nada além de, nas palavras de GOLDSCHMIDT, prognósticos de causalidade. São expectativas de influências da causa sobre o efeito.

Outra das características dos direitos processuais é sua análise como possibilidades processuais. Neste caso, a diferença destas possibilidades para com os direitos potestativos é que enquanto estes tem como objeto a constituição de relações, aqueles tem como finalidade a constituição de situações jurídicas. Além de que, estes são meios para formulação de um negócio jurídico, enquanto aqueles são meio para atos processuais (GOLDSCHMIDT, 1961, p. 75). O autor completa:

[...] el pleitar no envuelve una disposición del derecho, sino ni siquiera de la acción. En efecto, el incoar un proceso puede $y$, en todo caso, según la intención dela parte, ha de conducir al logro de ventajas jurídicas. Frente a eso no importa que, en caso de un resultado desfavorable, el pleitear equivalga a una disposición del derecho. El hecho de que las posibilidades procesales no se efectúen mediante negocios jurídicos, es decir, mediante declaraciones de voluntad, explica que la demanda no ejerza un derecho potesativo a pedir justicia, aunque, no obstante, aprovecha la posibilidad de constituir la

34 Todos os direitos processuais se encontram em uma relação de espera com uma resolução judicial, geralmente com a sentença. (Tradução Livre) 
expectativa de audiencia (de ser oido). (GOLDS. CHMIDT, 1961, p. 75-76) $)^{35}$

Para GOLDSCHMIDT (1961, p. 76-80) os direitos processuais não podem ser considerados de índole pública. A divisão entre direito público e privado se baseia no conceito de relação jurídica, que é uma visão estática do direito, portanto não pode ser concebida através de um processo através de uma concepção dinâmica do direito. Ao direito público pertence somente o fundamento do processo.

Para o autor, uma das questões mais importantes do princípio dispositivo do Direito Processual, é a possibilidade das partes de renunciar a estes direitos. Porém, para que haja esta renúncia, não é necessário que ocorra uma declaração de vontade da parte de que deseja renunciar. Neste ponto, é fundamental compreender que a renúncia pode se dar apenas com o não aproveitamento, com o desperdício, de uma possibilidade processual ou uma chance.

Consequentemente a este desperdício de uma chance, resulta que os direitos processuais se extinguem pela falta de uso. O autor exemplifica: "[...] cuando se reduce el Derecho justicial material de la acción a la posibilidad procesal correspondiente, la extinción de esta posibilidad procesal por desuso es la única forma en la cual se extinguen las obligaciones por el lapso de tiempo"36. (GOLDS. CHMIDT, 1961, p. 82)

A antítese de direito processual é a carga processual. Uma carga processual é a necessidade de realização de um ato proces-

35 O pleitear não envolve uma disposição do direito, nem mesmo da ação. Em efeito, ao iniciar um processo, pode e, em todo caso, segundo a intenção da parte, tem de conduzir ao logro da vantagens jurídicas. Frente a isto não importa que, em caso de um resultado desfavorável, o pleitear equivale a uma disposição do direito. $O$ feito de que as possibilidades processuais não se efetuam mediante negócios jurídicos, é dizer, mediante declarações de vontade, explica que a demanda não exerce um direito potestativo a pedir justiça, embora, não obstante, aproveita a possibilidade de construir a expectativa de audiência (de ser ouvido). (Tradução Livre)

36 Quando se reduz o direito justicial material da ação a possibilidade processual correspondente, a extinção desta possibilidade processual por desuso, é a única forma pela qual se extinguem as obrigações pelo lapso do tempo. (Tradução Livre) 
sual com a finalidade de prevenir um prejuízo processual ou, até mesmo, uma sentença desfavorável. Para GOLDSHMIDT (1961, p. 91-92), "Estas cargas son imperativos del propio interés. En eso se distinguen de los deberes, que siempre representan imperativos impuestos por el interés de un tercero o de la comunidad". ${ }^{37}$

Com uma visão exclusivamente processual, a carga é um imperativo do próprio interesse da parte, um imperativo que se manifesta por meio de uma ameaça de uma sentença desfavorável. Isto se justifica a partir de uma visão do processo como uma luta, pois é a luta das partes que integra a essência do pleito. Em uma luta, para que se possa ter êxito se faz necessário utilizar meios de ataques e de defesa. A consequência de um descuido é sofrer um golpe ou, no processo, a piora de sua situação jurídica processual. Ou seja, o aumento da perspectiva de uma sentença desfavorável.

Por isto, GOLDSCHMIDT (1961, p. 92-93) frisa que " $a$ los litigantes como tales, no les incumbe en el proceso en general nigún deber, ninguna obligación. Hay una carga, no un deber de fundamentar la demanda, de probar, de comparecer, de contestar" 38 . Desta forma, como a carga é um imperativo do próprio interesse da parte, não existe em contrapartida um direito do adversário ou do próprio Estado. Muito pelo contrário, nada melhor para o adversário do que a não liberação de cargas pela parte contrária. Enquanto para um, aumentam as expectativas de uma sentença favorável, para outro, aumentam as perspectivas de uma sentença desfavorável.

Neste ponto se encontra, em paralelo aos direitos processuais, a compreensão de que não existem obrigações. $\mathrm{O}$ que existe é uma relação estreita entre as cargas e as possibilidades processuais. Para o autor (GOLDSCHMIDT, 1961, p.93-94):

37 Estas cargas são imperativos do próprio interesse. Nisso se distinguem dos deveres, que sempre representam imperativos impostos pelo interesse de um terceiro ou da comunidade. (Tradução Livre)

38 Aos litigantes como tais, não os incumbe no processo em geral nenhum dever, nenhuma obrigação. Existe uma carga, não um dever de fundamentar a demanda, de provar, de comparecer, de contestar. (Tradução Livre) 
"cada posibilidad impone a la parte la carga de aprovechar la posibilidad al objeto de prevenir su pérdida. Puede establecerse el principio: la ocasión obliga o, más bien, impone una carga, y la más grave culpa contra sí mismo es desijar pasar la ocasión” ${ }^{39}$. Em uma análise mais profunda, o autor afirma que este princípio não possui apenas um valor no processo, mas também na vida. Conclui GOLDSCHMIDT, a respeito da necessidade de liberação de cargas:

La esencia del proceso como lucha de las partes y el peligro en que, por lo mesmo, se encuentra su situación jurídica, imponen a ellas la carga de una actividad aun cuando el acto requerido no prometa una ventaja con certidumbre bastante, es decir, aun cuando no sea el aprovechamiento de una posibilidad procesal ${ }^{40}$. (GOLDSCHMIDT, 1961, p. 94)

Porém, a despeito da necessidade e importância do aproveitamento de chances para realizar liberações de cargas, as vezes, é de maior interesse da parte silenciar a cometer uma declaração desfavorável. Ao invés de uma ação, uma omissão pode ser muito mais proveitosa em determinados casos. Neste ponto, vale o princípio: si tacuisses (apenas silencie). (GOLDSCHMIDT, 1961, p. 75)

$\mathrm{O}$ ato de não liberação de uma carga se chama rebeldia. Para GOLDSCHMIDT (1961, p. 98-100), a rebeldia do demandado é um mero descuido de uma carga. A consequência geral da rebeldia é a preclusão e está sempre acompanhada da não liberação de uma carga, que coincide com o não aproveitamento de uma oportunidade ou chance.

39 Cada possibilidade impõe à parte a carga de aproveitar a possibilidade do objeto de prevenir sua perda. Pode se estabelecer o princípio: a ocasião obriga ou impõe uma carga, e a mais grave culpa contra si mesmo é deixar passar a ocasião. (Tradução Livre)

40 A essência do processo como luta de partes e o perigo em que, pelo mesmo, se encontra sobre uma situação jurídica, impõe a elas uma atividade mesmo quando o ato requerido não prometa uma vantagem com muita segurança, é dizer, mesmo quando não seja o aproveitamento de uma possibilidade processual. (Tradução Livre) 
A grande "descoberta", realizada por James GOLDSCHMIDT, foi a inserção de novas categorias processuais. Categorias estas, que, aos poucos, foram admitidas pela maioria dos processualistas. Inicia-se por Niceto ALCALA-ZAMORA Y CASTILLO, que comenta a inserção destas novas categorias processuais:

Como se ve, una de las características más acusadas de la teoria de GOLDSCHMIDT es la de estar construida con nuevas categorias juridicas: los derechos y obrigaciones, inherentes a la idea de relacion jurídica, se reputan inadequados o incompatibles con el mecanismo del proceso, y en su reemplazo, como integrantes de la situacion jurídica, entran em juego expectativas, posibilidades, cargas y liberaciones de cargas $^{41}$ (ALCALA-ZAMORRA Y CASTILLO, 2000, p. 128)

Essas novas categorias devem sempre ser analisadas através de suas possibilidades e dependência de atitude e vontade das partes. Aury LOPES JR. elucida as possibilidades, chances processuais e a inexistência de obrigações:

[...] sempre que as partes estiverem em situação de obter, por meio de um ato, uma vantagem processual e, em última análise, uma sentença favorável, têm uma possibilidade ou chance processual. $\mathrm{O}$ produzir uma prova, refutar uma alegação, juntar um documento no devido momento são típicos casos de aproveitamento de chances.

Tampouco incumbem às partes obrigações, mas sim cargas processuais, entendidas como a realização de atos com a finalidade de prevenir um prejuízo processual e, consequentemente, uma sentença desfavorável. Tais atos

41 Como se vê, uma das características mais acusadas da teoria de GOLDSCHMIDT é estar construída com novas categorias jurídicas: os direitos e obrigações, inerentes a ideia de relação jurídica, se reputam inadequadas ou incompatíveis com o mecanismo do processo, e em substituição, como integrantes da situação jurídica, entram em jogo expectativas, possibilidades, cargas e liberação de cargas. (Tradução Livre) 
se traduzem, essencialmente, na prova de suas afirmações. (grifo do autor) (LOPES JR, 2008, p. 42)

Enrico Tullio LIEBMAN, na Itália, foi o principal baluarte de apoio e disseminação da doutrina Goldschmidtiana ${ }^{42}$. Foi ele, por sua amizade, quem aproximou Piero CALAMANDREI de uma aceitação da teoria da situação jurídica. $O$ italiano caracteriza as novas categorias de GOLDSCHMIDT da seguinte forma:

La situazione giuridia consiste propriamente nell'insieme di speranze e prospettive delle parti relativamente alla sentenza futura; [...] le prospettive in cui consiste la situazione giuridica sono collegate alla possibilità di produrre <evidenza> per mezzo degli atti processuali; e infine le posizioni soggettive che compongono la situazione giuridica (diritti e oneri processuali) hanno per contenuto le varie situazioni di vantaggio o di svantaggio in cui le parti possono trovarsi con riguardo alla speranza di ottenere una sentenza favorevole, secondo che attribuiscono l'aspettativa di un vantaggio processuale o la possibilità di conseguilo con un atto proprio, o viceversa costringano a comportarsi in un determinato modo se si voglia evitare uno svantaggio processuale. ${ }^{43}$ (LIEBMAN, 1962. p.137-138)

42 Enrico Tullio LIEBMAN realmente foi um dos grandes apoiadores da doutrina de James GOLDSCHMIDT, porém, em seu artigo "La obra científica de James Goldschmidt y la teoria de la relación jurídica", publicado em 1951 pela Revista de Derecho Procesal argentina, e trazida a esta obra acadêmica pelo texto original, em uma republicação na obra do próprio autor, rechaça a teoria da situação jurídica e reitera sua fidelidade a teoria da relação jurídica processual. "Posto il problema in questi termini, diventa possibile prendere posizione di fronte ad esso: e la preferenza dovrà essere per la teoria del rapporto, non per quella della situazione". (Posto o problema nestes termos, torna-se possível tomar uma posição: e a preferência será pela teoria da relação, e não por aquela da situação.) (Tradução Livre) (LIEBMAN, 1962, p.140)

43 A situação jurídica consiste propriamente na esperança e perspectiva da parte a uma sentença futura; esta perspectiva na qual consiste a situação jurídica está relacionada a uma possibilidade de produzir <evidenciar> por meio de um ato processual; e finalmente a posição subjetiva da situação jurídica (direito e encar- 


\section{Niceto ALCALA-ZAMORA Y CASTILLO também}

contribui nas definições das novas categorias processuais:

Las expectativas se refieren a la obtención de una ventaja procesal y, en definitiva, de una sentencia favorable; su contrafigura son las perspectivas de una sentencia desfavorable. A su vez, la parte que puede proporcionarse mediante un acto una ventaja procesal, tiene una posibilidad u ocasión procesal, mientras que si tiene que realizar un acto para prevenir un perjuicio procesal, le incumbe una carga procesal, de las que a veces libera a ley ${ }^{44}$.(ALCALAZAMORA Y CASTILLO, 2000, p. 128)

Porém, é fundamental fazer uma ressalva específica no que tange ao processo penal. Neste ramo processual, uma vez que embasado num processo acusatório e democrático ${ }^{45}$, a carga da prova está inteiramente nas mãos do acusador. Primeiro, porque é este que inicia a demanda com o oferecimento da denúncia (ou queixa-crime), e segundo porque o réu está inteiramente blindado pela presunção de inocência. Seria um grave equívoco pensar em uma "distribuição" das cargas probatórias no processo penal. A carga probatória está totalmente nos ombros

go processual) tem por conteúdo as várias situações de vantagem e de desvantagem em que a parte possa encontrar com relação à esperança de obter uma sentença favorável, conforme se da a expectativa de uma vantagem processual ou a possibilidade de conseguir com um ato próprio, ou vice-versa, obriga a parte a se comportar de um determinado modo a se desejar evitar uma desvantagem processual. (Tradução Livre)

44 As expectativas se referem à obtenção de uma vantagem processual e, em definitivo, de uma sentença favorável; sua contra-figura são as perspectivas de uma sentença desfavorável. A sua vez, a parte pode proporcionar, mediante um ato, uma vantagem processual, tem uma possibilidade ou ocasião processual, enquanto que para prevenir um prejuízo processual, incumbe-a uma carga processual das que as vezes a lei libera. (Tradução Livre)

45 Sobre processo penal democrático, vale a leitura da obra "Para um Processo $\mathrm{Pe}$ nal Democrático: Crítica à Metástase do Sistema de Controle Social" de Alexandre Morais da Rosa e Sylvio Lourenço da Silveira Filho. A referida obra procura "desvelar os condicionantes do discurso neoliberal e suas teorias contemporâneas no contexto do Direito e do Processo Penal Brasileiro. Promovendo uma crítica, de frente, ao modelo importado, especialmente como as novidades, acabaram sendo acolhidas sem maiores reflexões sérias e ao preço da democracia processual [...]". (ROSA; SILVEIRA FILHO. 2009, p. 99) 
do Ministério Público (ou do querelante). (LOPES JR, 2008, p. 42)

Contudo, como já visto anteriormente, estas novas categorias não inibem o conceito tradicional de relação jurídica material. Elas não estão submetidas e nem mesmo são imperativos ou poderes sobre a relação jurídica. $\mathrm{O}$ sucesso ou insucesso dos atos processuais no aproveitamento das chances criam expectativas de uma sentença favorável ou perspectivas de uma sentença desfavorável. Uma análise mais profunda permite perceber que, na realidade, são situações jurídicas das partes com relação ao objeto do processo.

Nas palavras de James GOLDSCHMIDT (1961, p. 62), a situação jurídica é o "estado de una persona desde el punto de vista de la sentencia judicial que se espera con arreglo a las normas jurídicas" ${ }^{{ }^{6}}$. Cada ato processual aumenta ou diminui a chance das partes de obter uma sentença a seu favor. Quando uma parte aproveita uma chance ela aumenta a sua expectativa de obter uma sentença de fundo favorável ao que está pleiteando. O inverso ocorre com a parte contrária. No momento em que o adversário obtém sucesso na liberação de uma carga, verbi gratia produz uma prova substanciosa, as chances da parte de obter uma sentença de fundo, com resultado favorável, diminuem. Veja-se figura ilustrativa (Figura 1):

O gráfico acima demonstra o funcionamento do processo de acordo com a Teoria da Situação Jurídica. O objeto do processo, que é o que será definido na sentença de fundo se move de acordo com cada ato processual executado pelas partes. Verbi gratia a Parte A consegue produzir uma prova contundente a favor de sua tese (liberação de carga), logo criará uma carga para a Parte B e aumentará suas expectativas por uma sentença favorável e diminuirá as perspectivas de uma sentença desfavorável (Figura 2).

46 Estado de uma pessoa desde o ponto de vista da sentença judicial que se espera com base nas normas jurídicas. (Tradução Livre) 
Porém, caso a Parte B consiga, através de um ato processual, demonstrar que a prova da Parte A foi produzida de maneira ilícita, ela aumentará suas expectativas por uma sentença favorável e diminuirá as perspectivas de uma sentença desfavorável (Figura 3). Desta forma criará uma nova situação jurídica processual movendo o objeto do processo para mais perto de si com relação à situação jurídica processual antiga.

Desta maneira, percebe-se a dinamicidade da Teoria da Situação Jurídica de James GOLDSCHMIDT. A cada ato processual, a cada procedimento cria-se uma nova situação jurídica no processo. O objeto do processo está em constante movimento, ora mais próximo de uma parte, ora da outra. Já a Teoria da Relação Jurídica de Oskar Von BÜLOW / Adolf WACH é estática, pois, devido as suas categorias e finalidade processual, ela fica atrelada ao direito material e sua concepção de segurança jurídica. A seguir dois gráficos: $\mathrm{O}$ primeiro (Figura 4) demonstra a Teoria da Situação Jurídica e o segundo (Figura 5) demonstra a Teoria da Relação Jurídica, ambos durante o desenrolar de um processo.

Ao analisar os dois gráficos acima, identifica-se a dinamicidade de uma das teorias e a qualidade de estática da outra. Oskar Von BÜLOW alega que a Relação Jurídica Processual é dinâmica, pois está em constante movimento e transformação (BÜLOW, 2005, p. 7), porém, esta teoria somente pode se considerar dinâmica, no que tange a uma série de atos que possuem uma simples marcha procedimental, lógica e evolutiva. $\mathrm{O}$ objeto do processo jamais se modifica nesta concepção. $O$ objeto do processo, em realidade, nem mesmo é percebido na teoria da relação jurídica.

Para além desta consideração estática do processo, James GOLDSCHMIDT difere o estado do objeto do processo antes e durante o processo. Antes do processo a relação jurídica material existente é juridicamente estática, pois não há conflito de interesses sobre ela. Porém, quando surge o processo, preenchese de dinamicidade e incerteza o objeto. Nas palavras do autor: 
El modo de ver o considerar el derecho, que convierte todas las relaciones jurídicas en expectativas o perspectivas de un fallo judicial de contenido determinado, puede llamarse una consideración dinámica del derecho en contraste con la consideración corriente, que es estática, porque enfoca todas las relaciones jurídicas como consecuencias jurídicamente necesarias de hechos presupuestos como realizados $^{47}$. (grifo do autor) (GOLDSCHMIDT, 1961, p. 64-65)

Para demonstrar o enfoque das afirmações quanto às diferenças entre as duas concepções, James GOLDSCHMIDT realiza uma comparação excelente ao campo político:

Durante la paz, la relación de un Estado con sus territorios y súbditos es estática, constituye un imperio intangible. En cuanto la guerra estalla, todo se encuentra en la punta de la espada; los derechos más intangibles se convierten en expectativas, posibilidades y cargas, y todo derecho puede aniquilarse como consecuencia de haber desaprovechado una ocasión o descuidado una carga; como al contrajo, la guerra puede proporcionar al vencedor el disfrute de un derecho que en realidad no le corresponde ${ }^{48}$. (GOLDSCHMIDT, 1961, p. 65)

47 O modo de ver ou considerar o direito, que converte todas as relações jurídicas em expectativas e perspectivas de uma decisão judicial de conteúdo determinado, pode ser chamada de uma consideração dinâmica do direito, em contraste com a consideração corrente, que é estática porque enfoca todas as relações jurídicas como consequências juridicamente necessárias de feitos pressupostos como realizados. (Tradução Livre)

48 Durante a paz, a relação de um Estado com seus territórios e súditos é estática, constitui um império intangível. Em quanto a guerra se instala, tudo se encontra na ponta da espada; os direitos mais intangíveis se convertem em expectativas, possibilidades e cargas, e todo o direito pode se aniquilar como consequência de não ter aproveitado uma ocasião ou descuidado uma carga; como ao contrário, a guerra pode proporcionar ao vencedor o desfrute de um direito que em realidade não lhe corresponde. (Tradução Livre) 


\section{A INTERDISCIPLINARIEDADE E A NAVEGAÇÃO DO PROCESSO NA EPISTEMOLOGIA DA INCERTEZA}

Ao equiparar o processo com uma guerra, o autor traz novas concepções e visões com relação ao processo. Visões estas que vão, desde uma expansão necessária da doutrina acadêmica tradicional, saindo do campo meramente jurídico e seguindo rumo aos estudos da arte da sociologia e estratégia, até concepções que levam a entender o processo à luz da epistemologia da incerteza.

Quanto ao campo do estudo de novas doutrinas, quem se arriscaria a afirmar que um bom conselho de Sun TZU (2007, P. 107) não tem validade em um processo? "Aquele que [...] faz pouco caso de seus oponentes, subestimando sua capacidade, certamente será derrotado por eles”. Esta afirmação do General Chinês não pode ser facilmente adaptada para um litígio judicial? Ora, não há dúvidas de que jamais deve-se subestimar a parte contrária, seja na guerra ou em um processo.

Se um processo é como uma guerra, estaria equivocado um cidadão se preparar para esta guerra? "A arte da guerra nos ensina a confiar, não na possibilidade de o inimigo não vir, mas sim, na nossa prontidão para recebe-lo” (TZU, 2007, p. 97). Não seria correto este cidadão contratar um advogado no momento que for firmar um contrato de grande importância? Isto não poderia evitar possíveis erros técnicos e, quiçá, um futuro processo? Ou até mesmo, no ato do interrogatório, o indiciado estar precavido de seu advogado, para evitar falar algo que possa ser prejudicial no futuro?

Pensando em estratégia, como ignorar Nicolau MAQUIAVEL (2007, p. 15): "Ao examinar esses principados [relativo ao capítulo anterior de sua obra], cumpre não esquecer outra consideração; isto é, saber se um Príncipe pode, em caso de agressão, defender sozinho o seu estado ou se deve recorrer sempre à ajuda alheia”. Uma empresa que possui várias causas trabalhistas e, portanto, contrata um escritório especializado 
em causas trabalhistas. Caso esta empresa venha a enfrentar um problema com a Receita Federal, não seria o caso de recorrer a ajuda de outro escritório especializado em direito tributário?

Esta necessidade de compreensão das várias doutrinas também trouxe um grande processualista italiano a reflexão. Piero CALAMANDREI, discípulo (e mestre) da escola processual italiana, chiovendiano ortodoxo por excelência, considerado o maior e mais fundamentado crítico das obras de James GOLDSCHMIDT ${ }^{49}$. Após a publicação da Teoria da Situação Jurídica em 1925 por James GOLDSCHMIDT, Piero CALAMANDREI, já em 1927, publicou, na Rivista di Diritto Processuale Civile, artigo, sob o título Il processo come situazione giuridica, tecendo severas críticas à esta nova teoria acerca da natureza jurídica do processo.

Entretanto, em 1950, seis anos antes de falecer, Piero CALAMANDREI rompe com a doutrina processual - dita à época - moderna e orna elogios à obra e vida de James GOLDSCHMIDT. Nos seus dois artigos: Il Processo Come Giuoco e Un Maestro di Liberalismo Processuale, Piero CALAMANDREI aceita a incerteza jurídica que ronda o processo, e insere em seus escritos as novas categorias processuais de GOLDSCHMIDT. ${ }^{50}$

O primeiro quesito apontado por CALAMANDREI, na obra O Processo Como Jogo (2002), é o aspecto psicológico do processo. Para enfatizar a real importância da influência dos fenômenos psíquicos no processo, o autor realiza uma comparação do conhecimento acerca do Código de Processo Civil com o jogo de xadrez:

A razão pela qual sair da universidade com licenciatura em processo civil, conseguida com conceito

49 MELENDO, Santiago Sentís. Morreu Piero Calamandrei. in CALAMANDREI, Piero. Instituições de Direito Processual Civil. $2^{\mathrm{a}}$ ed. Campinas: Bookseller. 2003 , p. 12.

50 Correta está a afirmação de que não se tratava de plena concordância com a teoria de James GOLDSCHMIDT. Porém, não se pode negar, que ocorreu uma mudança radical na maneira de ver, perceber, sentir e interpretar a ciência processual por CALAMANDREI. 
máximo e nota de louvor, não basta para tornar os advogados sagazes e eloquentes é muito similar, psicologicamente, àquela razão de comum experiência pela qual ninguém se torna hábil enxadrista unicamente por ter decorado um manual com as regras do jogo de xadrez. É verdade que, sem conhecê-las, não se pode jogar; [...] porém, mesmo se conhecendo as regras em teoria, aquilo que mais conta para aprender o jogo é vê-lo funcionando na prática, é experimentar como [as regras] são entendidas e como são respeitadas pelos homens que deveriam observá-las, contra quais resistências arriscam encontrar-se, com quais reações ou com quais tentativas de evasão têm de contar. ${ }^{51}$

Uma ou mais obras poderiam ser desenvolvidas elencando a interdisciplinaridade destas matérias. Portanto, não existe a menor dúvida, quanto a necessidade de traçar uma estratégia no campo processual. ${ }^{52}$ Para tanto, como não se pode ter certeza a respeito do resultado final da sentença do juiz, também se faz necessário compreender que o processo navega nas águas da incerteza. Navegação esta, muito mais turbulenta, no processo penal.

Se a carga probatória, no processo penal, está totalmente na mão da acusação, é incorreto afirmar que a defesa possui encargos. O que existe nestes casos é a assunção de riscos. Aury LOPES JR desenvolve esta teoria:

O que sim podemos conceber, indo além da noção inicial de situação jurídica, é uma assunção de riscos. Significa dizer que à luz da epistemologia da incerteza que marca a atividade processual e o fato de a sentença ser um ato de crença, de fé, a não produção de elementos de convicção para o julgamento

51 CALAMANDREI, Piero. O processo como jogo, GENESIS: Revista de Direito Processual Civil. Curitiba, n. 23, Jan./Mar. 2002, p. 191.

$52 \mathrm{~A}$ arte de saber jogar e traçar estratégias no processo está apresentada no trabaIho monográfico de conclusão de curso de graduação em Direito deste acadêmico. Mais especificamente no Capítulo 3 da referida obra. (PIAZZA, 2009) 
favorável ao seu interesse, faz com que o réu, acabe potencializando o risco de uma sentença desfavorável. Não há uma carga para a defesa, mas sim um risco. Logo, coexistem as noções de carga para o acusador e risco para a defesa. (LOPES JR, 2008, p. 42-43)

Aury LOPES JR. (2008, p. 43) entende que o conceito de carga está extremamente vinculado a uma noção de unilateralidade, portanto, é uma atribuição, e não uma distribuição. No processo penal, é do acusador a atribuição de toda carga probatória, inexistindo cargas para a defesa, e muito menos do juiz em um processo penal embasado em um sistema acusatório e democrático.

O autor (LOPES JR, 2008, p. 43) ensina que "a defesa assume riscos pela perda de uma chance probatória. Assim, quando facultado ao réu fazer prova de determinado fato por ele alegado, e não há o aproveitamento dessa chance, assume a defesa o risco inerente à perda de uma chance". No momento que qualquer parte perde uma chance processual, aumenta o risco de uma sentença desfavorável. Exemplo disto é o princípio do nemo tenetur se detegere. Ao exercer o direito ao silêncio, o réu não gera um prejuízo processual, pois inexiste carga. Porém, ocorre o extravio de uma chance, logo, eleva-se a perspectiva de uma sentença desfavorável.

Conclui Aury LOPES JR.:

Não há uma carga para a defesa exatamente porque não se lhe atribui um prejuízo imediato e tampouco possui ela um dever de liberação. A questão desloca-se para a dimensão da assunção do risco pela perda de uma chance de obter a captura psíquica do juiz. $O$ réu que cala assume o risco decorrente da perda da chance de obter o convencimento do juiz da veracidade de sua tese. (grifo nosso) (LOPES JR, 2008, p. 43) 
Todas estas exposições, com relação à guerra, estratégias, riscos e demais categorias processuais, reafirmam a ideia de que o processo navega em um oceano de incertezas. As próprias expectativas de sentença favorável e perspectivas de sentença desfavorável dependem diretamente do aproveitamento de chances e liberação de cargas e mais ainda do sucesso destes atos processuais. Em momento algum do processo, pode-se afirmar com certeza qual será o resultado da sentença.

LOPES JR. (LOPES JR, 2008, p. 44) afirma que: "O mundo do processo é o mundo da instabilidade, de modo que não há que se falar em juízos de segurança, certeza e estabilidade quando se está tratando com o mundo da realidade, o qual possui riscos que lhes são inerentes”.

Uma análise mais profunda, leva a crer que nem mesmo a máxima "coisa julgada" é detentora de total segurança ou certeza. Aury LOPES JR. compara a construção técnica-jurídica da coisa julgada com a matemática na visão de Albert EINSTEIN ${ }^{53}$ e afirma que:

É necessário destacar que o direito material é um mundo de entes irreais, numa vez que construído à semelhança da matemática pura, enquanto o mundo do processo [...] identifica-se com o mundo das realidades (concretização), pelo qual há um enfrentamento da ordem judicial com a ordem legal.

A dinâmica do processo transforma a certeza própria do direito material na incerteza característica da atividade processual. [...] A incerteza processual justifica-se na medida em que coexiste em iguais condições a possibilidade de

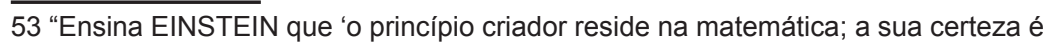
absoluta, enquanto se trata de matemática, abstrata, mas diminui na razão direta de sua concretização (...) as teses matemáticas não são certas quando relacionadas com a realidade e, enquanto certas, não se relacionam com a realidade'." (LOPES JR, 2008, p. 44) 
o juiz proferir uma sentença justa ou injusta. (LOPES JR, 2008, p. 44-45)

Dentro de um processo, o que se verifica é se o direito existe ou não, jamais poderá se presumir o direito como certo (enfoque material). A visão do processo como uma guerra demonstra que nem sempre quem tem razão vence, mas sim aquele que souber lutar melhor. Aqui está a importância de elaborar uma boa estratégia, saber aproveitar as chances, ter sucesso na liberação das cargas, reduzir ao máximo os riscos e conseguir fazer a maior captura psíquica possível do juiz. Se até mesmo os números são dotados de incerteza, quiçá então um processo.

\section{CONCLUSÃO}

Pelo exposto durante todo o desenvolvimento deste trabalho científico, é possível retirar vários ensinamentos e conclusões, acerca do desenvolvimento da doutrina ocidental sobre a ciência processual, em especial a natureza jurídica do processo. A compreensão do materialismo histórico do direito processual, leva a deduções reais sobre a evolução da maneira como a sociedade jurídica vê, compreende e maneja o processo.

Se fosse possível traçar uma linha, em que a história da teoria processual fosse o vetor, poder-se-ia realçar dois momentos, em especial, que modificaram totalmente a sistemática evolutiva do processo. Estes dois pontos foram verdadeiras revoluções na ordem jurídica processual, que transformaram substancialmente o pensamento crítico dentro das academias, e a prática forense dentro dos tribunais.

O primeiro deles, foi fixado pelo alemão Oskar Von BÜLOW, com o lançamento, em 1868, de seu livro "Teoria das Exceções e dos Pressupostos Processuais". Esta obra trouxe grandes evoluções para a ciência processual, tais como a total desvinculação entre direito processual e direito material, através da teoria dos pressupostos processuais, e a identificação da natureza jurídica do processo como Relação Jurídica Processual. 
A Teoria da Relação Jurídica Processual, apesar de enfrenta críticas contundentes, possui um século e meio de existência e ainda encontrar respaldo na maioria dos doutrinadores. Sua base foi a importação de categorias do direito material, como a ideia de relação jurídica e sujeitos da relação, para a esfera do direito processual.

Com a separação entre uma relação jurídica de cunho processual e uma relação jurídica de cunho material, Oskar Von BÜLOW, teve a proeza de revolucionar a ciência processual. Se em um momento existia uma verdadeira confusão entre as duas espécies de direitos (material e formal), após a publicação desta teoria, BÜLOW foi contemplado com o título de pai da ciência processual.

$\mathrm{Na}$ esteira dos principais seguidores da relação jurídica processual, veio Adolf WACH, Giuseppe CHOIVENDA e seus imediatos Francesco CARNELUTTI, Piero CALAMANDREI e Enrico Tullio LIEBMAN, a conhecida Escola Processual Italiana (ou Chiovendiana). Apesar de cada um possuir suas peculiaridades com relação a natureza jurídica do processo, o que ocorreu neste período foi um grande crossover com as particularidades de cada doutrinador.

$\mathrm{O}$ segundo momento que revolucionou o entendimento acerca da natureza jurídica do processo, e do qual tratou a maior parte deste artigo, foi a Teoria da Situação Jurídica de James GOLDSCHMIDT, em sua obra "Prozess als Rechtslage" (Processo como Situação Jurídica), publicada em 1925.

Em seu livro, após tecer críticas à teoria de BÜLOW, o autor foi em busca de quebrar os alicerces da principal teoria sobre a finalidade do processo, a Teoria da Exigência de Proteção Jurídica de Adolf WACH. Este entendeu que o processo é a forma legalmente regrada para aplicação do direito privado pelo Estado, porém seu opositor atacou, afirmando que esta exigência está regrada dentro do Direito Justicial Mateiral, e de maneira alguma possui uma índole processual e pública. 
Desta forma, GOLDSCHMIDT apresenta que a finalidade do processo é a simples obtenção de uma sentença favorável com força de coisa julgada. Portanto, uma vez que a sentença dependerá do sucesso ou não das partes no processo, logicamente o autor ensina que as leis são medidas para o juízo do juiz e que as antigas categorias processuais necessitam de revisão.

Assim, James GOLDSCHMIDT soterrou a existência de direitos e obrigações processuais. O que existem, na correta opinião do autor são novas categorias processuais, como: expectativas de uma sentença favorável, perspectivas de uma sentença desfavorável, cargas, liberação de cargas, riscos, ônus processuais e até mesmo captura psíquica do juiz.

As expectativas de uma sentença favorável e as perspectivas de uma sentença desfavorável são nexos jurídicos das partes. Estas dependem constantemente do aproveitamento ou não de um ato processual para aumentar ou reduzir suas expectativas e perspectivas. Portanto, quando uma das partes tem sucesso com uma liberação de cargas, esta parte automaticamente aumenta suas expectativas de uma sentença favorável e reduz suas perspectivas de uma sentença desfavorável. Já a parte contrária, terá uma redução de suas expectativas e um aumento de suas perspectivas.

O aproveitamento destes atos processuais e seu consequente sucesso ou insucesso é ligado aos ônus, riscos, cargas e a liberação de cargas. Quando uma das partes necessita produzir uma prova, ela possui uma carga, e portanto necessita liberar esta carga com sucesso para aumentar suas expectativas de uma sentença favorável. Já, por exemplo, quando outra parte segue a um interrogatório, e decide permanecer calada, como direito seu, ela não recebe um ônus por não ter liberado uma carga, mas aceita o risco de utilizar um direito.

Com a inserção destas novas categorias processuais, James GOLDSCHMIDT apresenta uma nova perspectiva da natura jurídica do processo. Pois, ao invés da relação jurídica de BÜLOW que é uma concepção estática do processo, e que 
somente pode ser vista como dinâmica quando analisada como uma sequência lógica e progressiva de atos processuais, GOLDSCHMIDT dá novos ares a concepção dinâmica do processo.

Estas categorias de GOLDSCHMIDT estão diretamente ligadas a finalidade do processo, ao objeto que é desejado através de uma sentença com força de coisa julgada. Portanto, a cada ato processual o objeto do processo como sentença de fundo e com força de coisa julgada é movimentado a cada instante. Torna-se rica em incertezas e vincula as partes a traçarem planos estratégicos para dimensionar suas chances e aproveitamento das novas categorias.

Esta riqueza no campo da incerteza e a necessidade de pensar o processo de maneira renovada, acaba por inserir novas concepções à natureza jurídica do processo. Estas novas concepções, vão desde características sociológicas, como é o exemplo das novas categorias (expectativas, chances, perspectivas, etc), até matérias de caráter lógico matemático, como a necessidade de encarar o processo como algo incerto. Estas lições acabam por nos remeter ao campo da estratégia e tática processual e os conselhos sobre a "captura psíquica do juiz" de Aury LOPES JR.

Finalizando esta pesquisa, optou-se por trabalhar uma importante implicação que toda esta discussão gerou: A redenção do grande jurista italiano Piero CALAMANDREI, à obra de James GOLDSCHMIDT.

As aclamações de Piero CALAMANDREI à James GOLDSCHMIDT, em seu texto "Il Processo Come Giuco" (O Processo como Jogo), levaram a doutrina do alemão a um novo patamar. Isto ocorreu, devido a um jurista internacionalmente reconhecido e respeitado, não que GOLDSCHMIDT não o fosse, mas advogar em causa própria não costuma trazer tão bons resultados, passa a defender estas teses e as apresenta em um texto muito eloquente.

CALAMANDREI expressa a real dogmática do processo, demonstra que para muito além da "justiça", como instrumento máximo da vontade Estatal, o que move as partes são os seus 
próprios interesses. Trouxe a visão daquele que magnificamente teorizou dentro da academia e viu e aprendeu a jogar com a prática do dia a dia dos tribunais.

Riassunto: Partendo delle concezioni moderne a rispeto della natura giuridica del processo, l'obiettivo di questo lavoro è presentare una visione diversa della maggior parte de quella studata nella accademia. Com questa finalita si presenta le due teorie piu accette per la comunita giuridica ocidentale: Al piu presto la teoria della relazione giuridica processuale di Oskar Von BÜLOW, com aiuto bibliografico di AdolfWACH, e della classica scuola processuale italiana e la sua contrapoziocione traverso della teoria della situazione giuridica processuale di James GOLDSCHMIDT. Realizza uno scambio di idee tra la Teoria dela domanda di protezione giuridica e il suo contrasto nella Teoria degli Imperativi. Studiando lê categorie processuali presentate per ambidue (diritti e obrigazioni di uma parte, e aspettative e perseguitare, oportunita, rischi, cariche e liberazione di cariche di l'altro) e conclude per la necessità di includere nuove categorie e materie, oltre della giuridica, allá sciencia processuale fino arrivare redenzione di Piero Calamendrei con la sua teoria del processo come um giocco.

Parole-chiavi: Natura giuridica del processo. Relazione Giuridica. Situazione giuridica. Protezione giuridica. Processo come giocco; Categorie processuale.

\section{REFERÊNCIAS}

ALCALA-ZAMORA Y CASTILLO, Niceto. Proceso, Autocompisición y Autodefensa: Conbritución al Estudio de Los Fines del Proceso. 3. ed. Cidade do México: Universidad Nacional Autónoma de México. 2000.

BÜLOW, Oskar Von. Teoria das Exceções e dos Pressupostos Processuais. Tradução: Ricardo Rodrigues Gama. Campinas: LZN. 2005. 
CALAMANDREI, Piero. Estudos de Direito Processual na Itália. Tradução: Karina Fumberg. Campinas: LZN, 2003.

CALAMANDREI, Piero. Instituições de Direito Processual Civil. Tradução: Douglas Dias Ferreira. 2. ed. Campinas: Bookseller, 2003.

CALAMANDREI, Piero. O processo como jogo, Revista GENESIS. Tradução: Roberto B. Del Claro. Curitiba, n. 23, p. 191-209, Jan./Mar. 2002.

CARNELUTTI, Francesco. Sistemas de Direito Processual Civil. Tradução: Hiltomar Martins Oliveira. 2. ed. São Paulo: Lemos e Cruz. 2004.

CHIOVENDA, Giuseppe. Instituições de Direito Processual Civil. Tradução: Paolo Capitanio. Campinas: Bookseller, 1998. 1.v.

GOLDSCHMIDT, James. Derecho Justicial Material. Buenos Aires: Ediciones Jurídicas Europa-América, S.A. 1959.

GOLDSCHMIDT, James. Principios Generales del Proceso: Teoria General del Proceso. 2. ed. Buenos Aires: Ediciones Jurídicas Europa-América, S.A. 1961. 1.v.

LIEBMAN, Enrico Tullio. Problemi del Processo Civile. Milão: Morano Editore. 1962.

LOPES JR., Aury. Direito Processual Penal e sua Conformidade Constitucional. 3. ed. Rio de Janeiro: Lumen Juris. 2008. 1v.

MAQUIAVEL, Nicolau. O Príncipe. Tradução: Ana Paula Pessoa. São Paulo: Jardim dos Livros. 2007.

MARQUES, José Frederico. Elementos de Direito Processual Penal. Campinas: Bookseller, 1997. 1.v.

MARQUES, José Frederico. Manual de Direito Processual Civil. 2. ed. Campinas: Millennium, 1998. 1.v.

PIAZZA, Valmor Júnior Cella. A Natureza Jurídica do Processo. São Paulo: Clube de Autores, 2009.

ROSA, Alexandre Morais da; SILVEIRA FILHO, Sylvio Lourenço da. Para um processo penal democrático: Crítica à Metástase do Sistema de Controle Social. Rio de Janeiro: Lumen Juris. 2009. 
TORNAGHI, Hélio. Comentários ao Código de Processo Penal. Rio de Janeiro: Revista Forense, 1956. 1v. 1t.

TZU, Sun. A Arte da Guerra. Tradução: Candida de Sampaio Bastos. São Paulo: DPL. 2007.

WACH, Adolf. Conferencias Sobre La Ordeanza Procesal Civil Alemana. Buenos Aires: Ediciones Juridicas Eupora-America, 1958.

WACH, Adolf. Manual de Derecho Procesal Civil. Buenos Aires: Ediciones Jurídicas Europa-America, 1977. 